

\section{Manipulating Courts in New Democracies}

When can the Executive manipulate the composition of a Court? What political factors explain judicial instability on the bench?

Using original field data from Argentina's National Supreme Court and all 24 Provincial Supreme Courts, Andrea Castagnola develops a novel theory to explain forced retirements of judges. She argues that in developing democracies the political benefits of manipulating the court outweigh the costs associated with doing so. The instability of the political context and its institutions causes politicians to focus primarily on short-term goals and to care mostly about winning elections. Consequently, judiciaries become a valuable tool for politicians to have under their control.

Contrary to the predictions of strategic retirement theory, Castagnola demonstrates that there are various institutional and non-institutional mechanisms for induced retirement which politicians have used against justices, regardless of the amount of support their party has in Congress. The theoretical innovations contained herein shed much needed light on the existing literature on judicial politics and democratization. Even though the political manipulation of courts is a worldwide phenomenon, previous studies have shown that Argentina is the theory-generating case for studying manipulation of high courts.

Andrea Castagnola is an assistant professor at the School of Politics and Government at Universidad Nacional de San Martin, Argentina. She was assistant professor at Flacso-Mexico and holds a Post-Doc from the University of Bergen, Norway. Her research focuses on judicial politics in Latin America and Comparative Politics. Her work has been published in journals such as British Journal of Political Science, Journal of Politics, Journal of Politics in Latin America and Política y Gobierno. 


\section{Routledge Studies in Latin American Politics}

10 Transforming Brazil A History of National

Development in the Postwar Era Rafael R. Ioris

11 Pharmaceutical Autonomy and Public Health in Latin America State, Society, and Industry in Brazil's AIDS Program Matthew Flynn

12 Civil-Military Relations in Post-Conflict Societies Transforming the Role of the Military in Central America Orlando J. Pérez

13 Re-Imagining Community and Civil Society In Latin America and the Caribbean

Edited by Gordana Yovanovich and Roberta Rice

14 Revolutionary Violence and the New Left

Transnational Perspectives Edited by Alberto Martín Álvarez and Eduardo Rey Tristán

15 Business-State Relations in Brazil

Challenges of the Port Reform Lobby Mahrukh Doctor
16 The Politics of Capitalist Transformation Brazilian Informatics Policy, Regime Change, and State Autonomy Jeff Seward

17 Negotiating Trade Liberalization in Argentina and Chile

When Policy creates Politics Andrea C. Bianculli

18 Understanding Cuba as a Nation From European Settlement to Global Revolutionary Mission Rafael E. Tarragó

19 Challenging the U.S.-Led War on Drugs

Argentina in Comparative Perspective

Sebastián Antonino Cutrona

20 Manipulating Courts in New Democracies Forcing Judges off the Bench in Argentina Andrea Castagnola

21 Crime, Violence and Security in the Caribbean M. Raymond Izarali 


\section{Manipulating Courts in New Democracies}

Forcing Judges off the Bench in Argentina

\section{Andrea Castagnola}


First published 2018

by Routledge

711 Third Avenue, New York, NY 10017

and by Routledge

2 Park Square, Milton Park, Abingdon, Oxon, OX14 4RN

Routledge is an imprint of the Taylor \& Francis Group, an informa business

(C) 2018 Taylor \& Francis

The right of Andrea Castagnola to be identified as author of this work has been asserted by her in accordance with sections 77 and 78 of the Copyright, Designs and Patents Act 1988.

All rights reserved. No part of this book may be reprinted or reproduced or utilized in any form or by any electronic, mechanical, or other means, now known or hereafter invented, including photocopying and recording, or in any information storage or retrieval system, without permission in writing from the publishers.

Trademark notice: Product or corporate names may be trademarks or registered trademarks, and are used only for identification and explanation without intent to infringe.

Library of Congress Cataloging in Publication Data

Names: Castagnola, Andrea, author.

Title: Manipulating courts in new democracies : forcing judges off the bench in Argentina / Andrea Castagnola.

Description: New York : Routledge, 2017. | Includes bibliographical references and index.

Identifiers: LCCN 2017027137 (print) | LCCN 2017027590 (ebook) |

ISBN 9781315271774 (Master) | ISBN 9781351986083 (WebPDF) |

ISBN 9781351986076 (ePub) | ISBN 9781351986069 (Mobipocket/

Kindle) | ISBN 9781138280724 (hardback : alk. paper)

Subjects: LCSH: Political questions and judicial power-Argentina. |

Courts of last resort-Argentina. | Judges-Argentina. | Justice,

Administration of-Argentina. | Democracy-Argentina.

Classification: LCC KHA2533 (ebook) | LCC KHA2533 .C37 2017 (print) |

DDC 347.82/035-dc23

LC record available at https://lccn.loc.gov/2017027137

ISBN: 978-1-138-28072-4 (hbk)

ISBN: 978-1-315-27177-4 (ebk)

Typeset in Times New Roman

by Wearset Ltd, Boldon, Tyne and Wear 
To Viole and Emma 
Castagnola's book analyzes the systematic use of a subtle instrument to change the composition of courts. She studies a mechanism for vacancy creation that depends on the drive of local executives rather than on the decisions of judges and that involves the use of informal pressures rather than institutional instruments. She superbly illustrates how weak executives use the instrument to build friendly courts and how in hegemonic party systems, executives use it to control factions. In a nutshell, the book introduces a new tool for the kit.

Catalina Smulovitz, Plenary Professor, Universidad Torcuato Di Tella

This book answers a key question: why and when do politicians force justices off the bench? The answer offered contributes to, but also challenges, our knowledge regarding courts and their political role in democratic polities. The book nicely specifies the institutional conditions under which politician's motivations prompt them to get "their own court" and supports the arguments with well-done and interesting quantitative and qualitative analyses on Argentinean Supreme and state courts over a long period of time. The book delves into the unchartered territory of the relationship between judges' stability in office and their independence, a critical topic in today's troubled democracies.

Julio Rios-Figueroa, Associate Professor of Political Science, Centro de Investigación y Docencia Económicas 


\section{Contents}

1 Introduction 1

2 Judicial Turnover in New Democracies: Forcing Judges off the Bench 11

3 The Political History of the Manipulation of the Argentinean Supreme Court

4 Forcing Justices off the Bench: Empirics from the Argentinean Supreme Court

5 The Persistent Manipulation of Courts: Empirics from the Provincial Supreme Courts in Argentina

6 The Institutional Determinants of Judicial Turnover at the Subnational Level

7 Conclusion

Index 


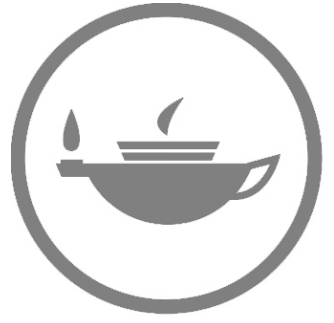

Taylor \& Francis Taylor \& Francis Group

http://taylorandfrancis.com 


\section{Introduction}

During recent years, the front pages of the newspapers have recurrently denounced the lack of independence of the judiciaries by revealing corruption cases as well as political manipulation of the justices. In November 2004, President Lucio Gutierrez from Ecuador with support from the congress removed 27 justices (out of 31) from the Supreme Court and seven judges (out of nine) from the Constitutional Tribunal as the result of explicit accusations that the justices and judges were politically loyal to the former president. In April 2005, the judiciary was, once again, the target of political manipulation when Gutierrez purged both the Supreme Court and the Constitutional Tribunal as a way to mitigate the critics and the opposition to his government. The country remained for seven months without a Supreme Court and for ten months without a Constitutional Tribunal. In July 2007 the Ecuadorian President Rafael Correa carried out a controversial restructuring of the judiciary, in which the Supreme Court changed not only its name (to the National Court of Justice) but also the total number of justices (reduced from 31 to 21). That same year, the Constitutional Tribunal was once again purged, in this case as a result of political confrontations with the executive. In Argentina in 1990, President Carlos Menem increased the number of sitting justices of the Supreme Court from five to nine and appointed six new justices to the bench, since two of the sitting justices had stepped off because of excessive political manipulation. In 2003, the Argentine President Néstor Kirchner induced the departure of six justices: two of them were impeached, and the other four were forced to leave via threats of impeachment and moral coercion.

The Latin American courts are not an exception; other judiciaries around the world also suffer political manipulation by the executive. For example in Pakistan, in 2007, President Pervez Musharraf requested the resignation of Chief Justice Iftikhar Chaudhry due to their political confrontation. The Chief Justice was physically restrained for several hours from leaving the president's office until he presented his resignation. In Zimbabwe, in February 2001, President Robert Mugabe threatened to remove the justices of the Supreme Court by force unless they resigned from the bench or reversed their rulings on recent land cases. A couple of days later, Mugabe forced Chief Justice Anthony Gubbay to resign from the bench, arguing that his government could not guarantee Gubbay's safety if he remained in office. Soon after Gubbay left the office, two other 


\section{Introduction}

high court justices (Ahmed Ebrahim and Nicholas McNally) were also asked to resign. ${ }^{1}$ As a way to ensure that the Supreme Court's decisions would be favorable to Mugabe's regime, in July 2001 the president packed the court by increasing from five to eight the number of sitting justices. Not surprisingly, the new court overturned the ruling of the old court on the land cases, as the government had expected.

Political manipulation of the judiciary is a deep-rooted problem for underdeveloped countries. The increased number of scandals and corruption cases within the judiciary has contributed to a great deterioration in the citizens' confidence in the institution. According to the Latinobarómetro surveys (2015), from 1996 to 2015 , on average, only 33 percent of Latin American citizens had confidence in the judiciary, less than half of the level of confidence that citizens had in the church (70 percent) and on the military (48 percent). Survey data from Argentina reveals a more dramatic situation regarding the level of trust in the national judiciary, on average, between 2004 and 2015, 17 percent of national citizens had confidence in the judiciary (Observatorio de la deuda social Argentina 2017). Figure 1.1 shows that since 2015 Argentinians had increased their level of trust in the judiciary but the overall performance is still low.

Evidently, the scandals related to the administration of justice, and the excessive political manipulation of judges has undermined the citizens' level of confidence. Montesquieu (1752) and Alexander Hamilton (Madison, Hamilton, \& Jay 1787-1788) would argue that the numerous attacks on the judiciary happened because the judiciary is the weakest of the three branches of government. Even though in most countries justices are appointed for life (or long-term tenures), the fact that the congress and the president are often in charge of both the appointing and removal processes makes justices, in underdeveloped countries, often vulnerable to those authorities. Studying the dynamic of vacancy creation in the Supreme Court can reveal valuable information about inter-branch relations, since judicial nominations offer a key political means for executives to enhance their control over the judiciary. Under normal circumstances, vacancies should be isolated events resulting from retirement, death or the end of the term (in those cases where justices do not have life tenure). However, if vacancies appear frequently, then this pattern may be indicating that there are other factors affecting the stability of a justice in office. In industrialized democracies like the US, vacancies in the Supreme Court are isolated events, since justices serve an average of 12.5 years (Zorn \& Van Winkle 2000); in contrast, in underdeveloped countries such as Bolivia (with a ten-year tenure), vacancies are much more common, because the average tenure is less than four years (Castagnola \& Liñán 2011). In Argentina, between 1900 and 2014, justices have stayed in office on average less than seven years; furthermore, every 1.2 years there has been a vacancy in the court. At the subnational level in Argentina there is also great variation in the stability of the justices: between 1983 and 2009, justices from Corrientes with life tenure remained in office an average of 2.5 years, while justices from Buenos Aires, also with life tenure, have served, on average, 8.41 years. These significant variations in the level of judicial turnover reveal that in 


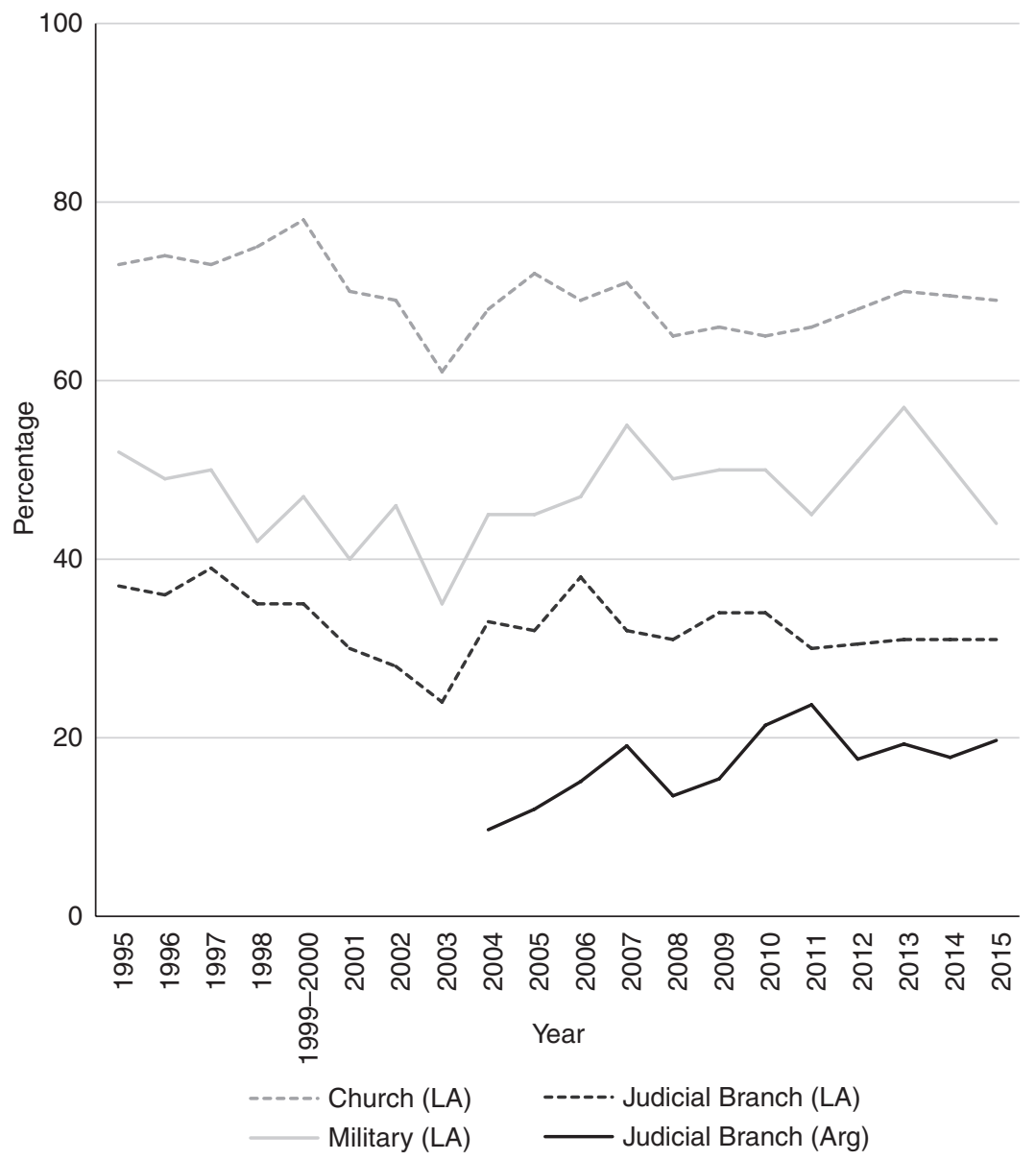

Figure 1.1 Public Trust (\%).

Sources: Observatorio de la deuda social Argentina (2017) and Latinobarómetro (2015).

some cases justices do not voluntarily leave the bench; rather, there must be other factors influencing their departure. Why do justices remain in office for such a short time despite having life tenure or long-term tenure? What factors account for variations in judicial turnover across cases? The objective of this research is to provide an answer to these questions by systematically examining what factors have influenced justices' stability in office over time in both the Argentine National and the Provincial Supreme Courts. By studying the timing of judicial turnover it is possible to identify whether justices voluntarily step off the bench or leave as the result of political manipulation by the incoming executive. This close examination of the instability of Argentine justices aims to shed light on debates about judicial independence in developing democracies. 
More generally, the puzzle of justices' instability in office challenges several assumptions about executive-court relations and judicial behavior. First, the American political literature offers a model of judicial turnover based on the assumption that the justice's own decision to step off the bench is influenced by whether or not the justice shares the same political preferences as the president and the Senate (Hagle 1993; Spriggs \& Wahlbeck 1995; Zorn \& Van Winkle 2000). The rationale of the strategic retirement strategy is based on the idea that justices are willing to give their seats to another like-minded justice but not to a justice with opposite political preferences. The underlying assumption of this argument is that the longevity of justices in office is mainly determined by the justices' own decision. Even though this assumption holds perfectly for the American case, for underdeveloped countries it is problematic, because there the longevity of justices in office appears to be determined by the executive rather than by the justices themselves. As the earlier examples illustrated, in those countries vacancies in the high court are basically triggered by presidents either inducing the departure of justices through undemocratic decisions, or threatening them with impeachment or moral coercion. Historical data on justices of the US and Argentine Supreme Courts reveals that in Argentina justices have not voluntarily stepped off the bench. Between 1900 and 2007 in the US Supreme Court, 54 justices departed from the bench mainly due to death (46 percent) and voluntary retirement (44 percent), whereas a small number (10 percent) resigned for other reasons (Ward 2003). In Argentina, in comparison, during that same period $83^{2}$ justices departed from the bench for these reasons: 37 percent were removed as a consequence of a change in the political regime from military to democratic or vice versa; 31 percent resigned from office as a consequence of a change of government within the same political regime; 20 percent died while in office; 6 percent were impeached; and the remaining 6 percent retired voluntarily (Kunz 1989; Pellet Lastra 2001; Bercholc 2004; Tanzi 2005). ${ }^{3}$ Consequently, in Argentina voluntary departure (as the result of natural legal - that is, retirement - and biological - that is, death - conditions) was not the most common explanation for the high judicial turnover.

Second, there has been a large increase in the study of judicial independence in Latin America. Even though Argentina has the most studied Supreme Court in Latin America (Kapiszewski \& Taylor 2008), the existing literature does not explicitly address the factors that influence a justice's decision to leave office. Studies to date affirm that life tenure for Argentine justices is not respected, given that the way justices vote (regarding, say, the constitutionality of a proposed law) can account for their instability in office (Iaryczower, Spiller, \& Tommasi 2002; Scribner 2004; Helmke 2005). More precisely, these studies focus on how political incentives and the political environment shape the justices' decisions and assume that those decisions ultimately determine the justices' stability in office; however, no systematic research empirically tests this assumption. Thus, if justices can regulate their stability on the bench by whether or not they rule against the ruler, then why don't they simply do that? Why is there, in fact, a high judicial turnover in the country? In other words, the 
importance of the justices' voting behavior as a mechanism of survival strategy on the bench is called into question.

The puzzle of justices' instability in office also raises concern about executive-court relations. Along with the previous hypothesis, another relevant untested assumption in the literature is that only those presidents with strong political power (i.e., unified governments with supermajorities in the legislature) can craft a supportive court and affect justices' stability in office (Iaryczower et al. 2002; Bill Chávez 2004). This assumption is related to the previous one, since it implies that only those presidents who have the political power to formally remove a justice from office (i.e., by impeachment) will obtain a supportive court. These studies are severely limited because they examine only whether or not the president has the political power to remove a justice from office, but not if it is only those strong presidents who actually do so. Even though this assumption seems convincing, governments rarely have had supermajorities in the legislature sufficient to impeach a justice. If that is the case, how can the high instability of justices be explained? Were those justices removed from office only by those presidents who had the political power formally to do so?

As a way to fill the gap between the American and the Latin American theories, this study begins with the alternative hypothesis that in developing democracies, the greater the political proximity between the ruling executive and the justice, the lower the probability that the justice will leave office. In contrast, in industrialized democracies, judicial turnover is independent of ideological changes in the executive. This is because executives, while in power, want to have a supportive court as a way to maximize their political influence on the decisions of the judiciary. The executive can craft a supportive court not only by appointing friendly justices, as the American literature has long recognized, but more interestingly by influencing when a vacancy will occur either by removing unfriendly justices or by packing the court with loyal justices.

\section{Design and Methodology}

Argentina, in terms of both the National Supreme Court and the Provincial Supreme Courts, represents a textbook case for the study of factors affecting the instability of justices in office. Argentina is a federal country with separate judicial entities at the provincial level; moreover, each province is autonomous vis-à-vis the national government in the design of its own institutions, producing a high degree of internal heterogeneity in the constitutional design. Precisely because of the persistent institutional instability, where from 1930 to 1983 democratic and military governments ruled interchangeably followed by a period when the administration changed as the result of party competition, Argentina can be considered a developing democracy. In the early ' 80 s, the country, as well as other countries in the world, entered what is known as the third wave of democratization and thus the democratic institutional consolidation process (Huntington 1991).

Previous studies have also shown that Argentina is the theory-generating case for studying executive-court relations in developing democracies. Argentina was 


\section{Introduction}

used in studies as the classical example of a third wave democracy born with a weak judiciary (Bill Chávez 2004). The constant political manipulation by the executive, and the incapacity of the judiciary to limit attacks on itself, illustrate the difficult situation also present in other developing democracies. Another group of scholars (Iaryczower et al. 2002; Scribner 2004; Helmke 2005) chose Argentina as a case study to demonstrate that, even with the presence of a weak judiciary, Argentine justices have challenged executives by strategically ruling against them; what they reveal, however, is simply that executives do not have total control over the justices' decisions. ${ }^{4}$ However, these studies have clearly overlooked the high degree of internal heterogeneity in the country, since most of the research was carried out at the national level (i.e., on the National Supreme Court). Even though Bill Chavez (2004) incorporates into her research two Argentine provinces (Mendoza and San Luis), the research illustrates only that there is an internal heterogeneity at the subnational level; it does not examine the causal connections in the other provinces that have undergone other experiences. As a way to overcome this deficit, this research employs the subnational comparative method (including all 23 Provincial Supreme Courts) ${ }^{5}$ to analyze within-country variations (Snyder 2001). It is precisely these variations at the subnational level that would not only shed light on the factors that account for those differences but also would allow development of a mid-range theory about the stability of justices in office that should be applicable to other developing democracies.

More generally, studying the provincial judiciaries in Argentina is of substantive relevance. First, the provincial judiciaries play a central role in local politics, since governors envision this institution as another key political resource to enhance their power. Studying the judiciary over time and across provinces can contribute to understanding how the configuration of local power, as well as diverse institutional design, affects the stability of the justices in office. By doing so, this research redirects attention to the neglected role of the separation of powers at the subnational level, the most overlooked aspect of the literature on federalism (Cameron \& Falleti 2005). Second, studying the provincial judiciaries also provides valuable information about the differences and similarities between the trajectories of the national Supreme Court and the provincial Supreme Courts. The subnational comparative method helps to explain the variations not only across space and time but also across different political regimes (Snyder 2001).

The research proceeds as follows. Chapter 2 discusses the main contributions and ideas underlying the existing literature. It traces the main theories of judicial turnover both within and outside the American literature, and then develops a theory of vacancy creation that builds on the main contributions of existing research. This theory provides a unified framework for bringing together the preferences and incentives of executives for crafting a supporting court with the different strategies employed by the executives for forcing the retirement of certain justices from the bench. Specifically, the chapter examines how executives can trigger institutional and non-institutional strategies so as to obtain a friendly court. 
Chapter 3 assesses the adequacy of the theory of vacancy creation by an historical examination of executive-court relations in Argentina. Using primary and secondary sources, the chapter traces the different ways in which justices have stepped off the bench from 1916 to 2014. Until the massive impeachment trial of four of the five members of the Supreme Court in 1946, justices had remained on the bench for long periods, the main reason for their departures being biological (death) and legal (retirements). However, since 1946 justices have been highly unstable on the bench, with the executive in most cases having forced their retirement. As the 1946 impeachment trial constitutes a critical junction in the history of the executive-court relationship, the chapter shows how the events after the impeachment trial have reinforced practices undermining the independence of the justices and increasing the cost of changing the direction of events.

Chapter 4 provides a quantitative analysis of the theory of vacancy creation for the Argentine justices of the National Supreme Court between 1916 and 2014. The evidence shows that the preferences and incentives of the executives can affect the stability of the justices on the bench. Specifically, the data reveal that politics matters when accounting for induced retirements from office, whereas non-political reasons account for non-induced retirements. Justices with similar political preferences as the ruling executive are less likely to be forced to step off the bench than justices with different political preferences. Moreover, political loyalties between justices and executives were proved to be more sophisticated than expected, since what matters is the loyalty of the justices to the faction of the political party of the appointing executive rather than to the political party itself. Finally, the data also show that there is a timing effect with regard to involuntary retirements, since justices are more likely to leave the bench at the beginning of a new administration, revealing that executives prefer to craft a supportive court early in their term so as to leverage their political power. Overall, judicial turnover is not a random event but rather the result of the strategic political behavior of the ruling executive.

Chapter 5 uses original data gathered from the provincial Supreme Courts to systematically examine the factors that account for the judicial instability at that level since 1983. Descriptive statistics reveal that provincial justices have been on average more unstable than the justices from the National Supreme Court both before 1983 and afterwards. Governors have recurrently reshuffled their local courts so as to craft a more favorable judiciary, and the qualitative data gathered about the departures of the justices shows that governors have triggered both institutional and non-institutional mechanisms of vacancy creation. Because at the subnational level there is significant heterogeneity, it was possible to elucidate more clearly how political factors matter under different scenarios. In those provinces with a single-party system (where the same political party has ruled since 1983), governors would not trust justices appointed by a governor from a different political faction. Intra-party competition plays a central role in those provinces to account for judicial instability. However, in provinces with a multi-party system, governors do not trust justices appointed by a governor from 
a different political party as well as from a different political faction (as, for example, in Córdoba with Mestre, or in Santiago del Estero with Iturre). Furthermore, the quantitative data reveal that, even though the political proximity between the governors and the justices matters in accounting for the judicial instability, institutional rules may matter as well. Governors have recurrently changed the regulations regarding the number of sitting justices to craft a more favorable court either by enlarging its size (to create new vacancies) or by reducing it (to permit removing unfriendly justices). Institutional rules appear to be a significant factor affecting the stability of the justices.

The findings of the previous chapter laid the groundwork for Chapter 6, which aims to explore to what extent institutional rules can facilitate or constrain judicial turnover. The fact that the Argentine provinces are autonomous and retain all the power that was not specifically entrusted to the national government allows them to dictate their own constitutions. This is precisely the reason for exploring how different institutional rules influence the stability of the justices on the bench. This chapter uses original data collected from the provincial constitutions, as well as other laws and regulations related to the functioning of the local supreme courts since 1983. The analysis of the 54 provincial constitutions suggests that there is great heterogeneity regarding the institutional design in the provincial judiciaries. Chapter 6 presents an econometric model designed to assess the combined effect of institutional rules and political factors (analyzed in the previous chapters), so as to determine to what extent institutional rules can promote or impede judicial turnover. The findings in this chapter provide evidence to support the theory of vacancy creation. First, the model reveals that political factors, rather than institutional rules, play a central role in accounting for judicial instability. Having life tenure is the only institutional rule that matters in accounting for judicial instability, while rules regarding appointment and removal processes do not. Second, it was demonstrated that changes in the institutional rules, rather than the rules themselves, help account for judicial turnover on the bench; which suggests that governors have triggered both institutional and non-institutional mechanisms of vacancy creation to manipulate the composition of the court.

The last chapter summarizes the main findings of this research and explores the theoretical relevance of the findings for the study of judicial instability in other developing democracies such as Peru and Indonesia. The latter become interesting case studies to extend the theory of vacancy creation in which executives manipulate the formation of the court. However, the experiences of other countries in the region such as Ecuador reveal that, in fact, there are different mechanisms of vacancy creation that still need to be addressed by future research. Ecuador illuminates a different way in which judicial turnover is driven - that is, by a coalition of parties in congress. Ecuador combines features of strong presidentialism with a highly fragmented party system in which the president's party rarely has control over the congress; thus, it is the congress rather than the president that manipulates the formation of the court (Shugart \& Carey 1992; Shugart 1995: Mejía Acosta 2006). 


\section{Notes}

1 By December 2001, Justice McNally had resigned from the court due to the executive's excessive abuse of the judiciary, followed by Justice Ebrahim in March 2002.

2 The situation is even more problematic when the size of the Supreme Court is considered. Since 1869 the number of US justices was fixed at nine, whereas in Argentina during this period the number of justices has varied between five and nine.

3 In other nascent democracies, such as Colombia, there are more serious and severe ways of creating vacancies such as the massive killing of the justices of the Supreme Court that took place in 1985.

4 Moreover, and contrary to theoretical expectations of judicial independence, these studies elucidate that justices who lacked independence, because of the unstable institutional context, were precisely the ones who challenged the executives: Helmke, G. (2005). Courts Under Constraints: Judges, Generals, and Presidents in Argentina.

5 Ciudad Autónoma de Buenos Aires was excluded from the sample, since the Supreme Tribunal only started to function in 1998.

\section{References}

Bercholc, J. (2004). La Independencia de la Corte Suprema a través del control de Constitucionalidad respecto a los otros poderes políticos del Estado (1935-1998). Buenos Aires, Argentina: Ediar.

Bill Chávez, R. (2004). The rule of law in nascent democracies. Judicial politics in Argentina. Stanford, California, Stanford University Press.

Cameron, M. A., \& Falleti, T. G. (2005). Federalism and the subnational separation of powers. Publius, Spring, 245-271.

Castagnola, A., \& Liñán, A. P. (2011). Bolivia: The rise (and fall) of judicial review. In G. Helmke, \& J. Rios-Figueroa (Eds.), Courts in Latin America. Cambridge: Cambridge University Press.

Hagle, T. M. (1993). Strategic retirements: A political model of turnover on the United States Supreme Court. Political Behavior, 15(1), 25-48.

Helmke, G. (2005). Courts under constraints: Judges, generals, and presidents in Argentina. New York: Cambridge University Press.

Huntington, S. (1991). The third wave: Democratization in the late twentieth century. Oklahoma: University of Oklahoma Press.

Iaryczower, Matias, Spiller, Pablo T., \& Tommasi, Mariano (2002). Judicial independence in unstable environments, Argentina 1935-1998. American Journal of Political Science, 46(4), 699-716.

Kapiszewski, D., \& Taylor, M. M. (2008). Doing courts justice? Studying judicial politics in Latin America. Perspectives on politics, 6(4), 741-767.

Kunz, A. E. (1989). Los Magistrados de la Corte Suprema de Justicia de la Nacion (1930-1983). Cuadernos de investigaciones, 15.

Latinobarómetro (2015). La confianza en América Latina 1995-2015. Santiago de Chile: Latinobarómetro.

Madison, James, Hamilton, Alexander, \& Jay, John (1787-1788). The Federalist Papers. New York, Bantam Classic.

Mejía Acosta, A. (2006). Crafting legislative ghost coalitions in Ecuador. Informal institutions and economic reform in an unlikely case. In G. Helmke, \& S. Levitsky (Eds.), Informal institutions \& democracy. Lessons from Latin America (pp. 69-84). Baltimore, Maryland: The Johns Hopkins University Press. 


\section{Introduction}

Montesquieu, C. d. S. (1752). The spirit of laws. (Mr. Nugent, Trans.) (2 vols.). London: J. Nourse, and P. Vaillant.

Observatorio de la deuda social Argentina (2017). Confianza en las Instituciones Judiciales. www.uca.edu.ar/uca/common/grupo68/files/2016-observatorio-Figura3-Confianza-en-elPoder-Judicial.pdf. Buenos Aires, Pontificia Universidad Católica Argentina.

Pellet Lastra, A. (2001). Historia Política de la Corte (1930-1990). Buenos Aires, Argentina, Ad-Hoc.

Scribner, D. (2004). Limiting presidential power: Supreme Court-Executive relations in Argentina and Chile. Political Science. San Diego, California: University of California, San Diego, 498 (PhD dissertation).

Shugart, M. S. (1995). The electoral cycle and institutional sources of divided presidential goverment. American Political Science Review, 89(2), 327-343.

Shugart, M. S., \& Carey, J. M. (1992). Presidents and assemblies: Constitutional design and electoral dynamics. Cambridge, England; New York: Cambridge University Press.

Snyder, R. (2001). Scaling down: The subnational comparative method. Studies in Comparative International Development, 36(1), 93-110.

Spriggs, J. F. I., \& Wahlbeck, P. J. (1995). Calling it quits: Strategic retirement on the federal courts of appeals, 1893-1991. Political Research Quarterly, 48(3), 573-597.

Tanzi, H. J. (2005) Historia Ideológica de la Corte Suprema de Justicia de la Nación (1930-1947). IUSHISTORIA Revista Electronica, 1, 1-148.

Ward, A. (2003). Deciding to leave. The politics of retirement from the United States Supreme Court. New York: State University of New York.

Zorn, C. J., \& Van Winkle, S. R. (2000). A competing risks model of Supreme Court vacancies, 1789-1992. Political Behavior, 22(2), 145-166. 


\section{Introduction}

Bercholc, J. (2004). La Independencia de la Corte Suprema a través del control de Constitucionalidad respecto a los otros poderes políticos del Estado (1935-1998). Buenos Aires, Argentina: Ediar.

Bill Chávez, R. (2004). The rule of law in nascent democracies. Judicial politics in Argentina. Stanford, California, Stanford University Press.

Cameron, M. A. , \& Falleti, T. G. (2005). Federalism and the subnational separation of powers. Publius, Spring, 245-271.

Castagnola, A. , \& Liñán, A. P. (2011). Bolivia: The rise (and fall) of judicial review. In G. Helmke, \& J. Rios-Figueroa (Eds.), Courts in Latin America. Cambridge: Cambridge University Press.

Hagle, T. M. (1993). Strategic retirements: A political model of turnover on the United States Supreme Court. Political Behavior, 15(1), 25-48.

Helmke, G. (2005). Courts under constraints: Judges, generals, and presidents in Argentina. New York: Cambridge University Press.

Huntington, S. (1991). The third wave: Democratization in the late twentieth century. Oklahoma: University of Oklahoma Press.

laryczower, Matias, Spiller, Pablo T. , \& Tommasi, Mariano (2002). Judicial independence in unstable environments, Argentina 1935-1998. American Journal of Political Science, 46(4), 699-716.

Kapiszewski, D. , \& Taylor, M. M. (2008). Doing courts justice? Studying judicial politics in Latin America. Perspectives on politics, 6(4), 741-767.

Kunz, A. E. (1989). Los Magistrados de la Corte Suprema de Justicia de la Nacion (1930-1983). Cuadernos de investigaciones, 15.

Latinobarómetro (2015). La confianza en América Latina 1995-2015. Santiago de Chile: Latinobarómetro.

Madison, James , Hamilton, Alexander , \& Jay, John (1787-1788). The Federalist Papers. New York, Bantam Classic.

Mejía Acosta, A. (2006). Crafting legislative ghost coalitions in Ecuador. Informal institutions and economic reform in an unlikely case. In G. Helmke, \& S. Levitsky (Eds.), Informal institutions \& democracy. Lessons from Latin America (pp. 69-84). Baltimore, Maryland: The Johns Hopkins University Press.

Montesquieu, C. d. S. (1752). The spirit of laws. (Mr. Nugent, Trans.) (2 vols.). London: J. Nourse, and P. Vaillant.

Observatorio de la deuda social Argentina (2017). Confianza en las Instituciones Judiciales. www.uca.edu.ar/uca/common/grupo68/files/2016-observatorio-Figura3-Confianza-en-elPoder-Judicial.pdf. Buenos Aires, Pontificia Universidad Católica Argentina.

Pellet Lastra, A. (2001). Historia Política de la Corte (1930-1990). Buenos Aires, Argentina, Ad-Hoc.

Scribner, D. (2004). Limiting presidential power: Supreme Court-Executive relations in Argentina and Chile. Political Science. San Diego, California: University of California, San Diego, 498 (PhD dissertation).

Shugart, M. S. (1995). The electoral cycle and institutional sources of divided presidential goverment. American Political Science Review, 89(2), 327-343.

Shugart, M. S. , \& Carey, J. M. (1992). Presidents and assemblies: Constitutional design and electoral dynamics. Cambridge, England; New York: Cambridge University Press.

Snyder, R. (2001). Scaling down: The subnational comparative method. Studies in Comparative International Development, 36(1), 93-110.

Spriggs, J. F. I. , \& Wahlbeck, P. J. (1995). Calling it quits: Strategic retirement on the federal courts of appeals, 1893-1991. Political Research Quarterly, 48(3), 573-597.

Tanzi, H. J. (2005) Historia Ideológica de la Corte Suprema de Justicia de la Nación (1930-1947). IUSHISTORIA Revista Electronica, 1, 1-148.

Ward, A. (2003). Deciding to leave. The politics of retirement from the United States Supreme Court. New York: State University of New York.

Zorn, C. J. , \& Van Winkle, S. R. (2000). A competing risks model of Supreme Court vacancies, 1789-1992. Political Behavior, 22(2), 145-166. 


\section{Judicial Turnover in New Democracies}

Atkinson, David N. (1999). Leaving the bench. Supreme Court justices at the end. Kansas: University Press of Kansas.

Aydın, Aylin (2013). Judicial independence across democratic regimes: Understanding the varying impact of political competition. Law \& Society Review, 47(1), 105-134.

Bailey, Michael A. , \& Yoon, Albert (2011). "While there's a breath in my body": The systemic effects of politically motivated retirement from the Supreme Court. Journal of Theoretical Politics, 23(3), 293-316.

Barrow, Deborah J. , \& Zuk, Gary (1990). An institutional analysis of turnover in the lower federal courts, 1900-1987. The Journal of Politics, 52(2), 457-476.

Bill Chávez, Rebecca (2004). The rule of law in nascent democracies. Judicial politics in Argentina. Stanford, California: Stanford University Press.

Bonneau, Chris W. (2005). Electoral verdicts. Incumbent defeats in state Supreme Court elections. American Politics Research, 33(6), 818-841.

Bonneau, Chris W. , \& Hall, Melinda Gann (2003). Predicting challengers in state Supreme Court elections: Context and the politics of institutional design. Political Research Quarterly, 56(3), 337-349.

Brenner, Saul (1999). The myth that justices strategically retire. The Social Science Journal, 36(2), 431-439.

Brinks, Daniel , \& Blass, Abby (2010). The role of diffusion and domestic politics in judicial design: A theoretical framework and preliminary results. Presented at the Latin American Studies Association, Toronto, October 6-9.

Burbank, Stephen B. , Plager, S. Jay , \& Ablavsky, Gregory (2012). Leaving the bench, 1970-2009: The choices federal judges make, what influences those choices, and their consequences. In Scholarship at Penn Law. Paper 416: http://lsr.nellco.org/upenn_wps/416. Callen, E. , \& Leidecker, H. Jr. (1971). A mean life on the Supreme Court. American Bar Association Journal, 57(December), 1188-1192.

Cameron, Charles M. (2002). Judicial independence: How can you tell it when you see it? In S. B. Burbank , \& B. Friedman (Eds.), Judicial independence at the crossroads. An interdisciplinary approach. Thousand Oaks, California: Sage Publication.

Camp Keith, Linda (2002). Constitutional provisions for individual human rights (1977-1996): Are they more than mere "window dressing?" Political Research Quarterly, 55(1), 111-143.

Clark, David S. (1975). Judicial protection of the constitution in Latin America. Hastings Constitutional Law Quarterly, 2, 405-442.

Diamond, Larry (1999). Developing democracy - toward consolidation. Baltimore: The Johns Hopkins University Press.

Elster, Jon (1988). Introduction. In J. Elster , \& R. Slagstad (Eds.), Constitutionalism and democracy. Cambridge: Cambridge University Press.

Epstein, Lee , \& Segal, Jeffrey A. (2005). Advice and consent. The politics of judicial appointments. Oxford: Oxford University Press.

Epstein, Lee, Knight, Jack , \& Shvetsova, Olga (2002). Selecting selection systems. In S. B. Burbank, \& B. Friedman (Eds), Judicial independence at the crossroads. An interdisciplinary approach (pp. 191-226). Thousand Oaks: SAGE Publications.

Feld, Lars P. , \& Voigt, Stefan (2003). Economic growth and judicial independence: Crosscountry evidence using a new set of indicators. European Journal of Political Economy, 19, 497-527.

Finkel, Jodi S. (2008). Judicial reform as political insurance: Argentina, Peru, and Mexico in the 1990s. Notre Dame: University of Notre Dame Press.

Frühling, Hugo E. (1993). Human rights in constitutional order and in political practice in Latin America. In D. Greenberg , S. N. Katz , M. B. Oliviero , \& S. C. Wheatley (Eds.),

Constitutionalism and democracy. Transitions in the contemporary world. New York: Oxford University Press.

Ginsburg, Tom (2003). Judicial review in new democracies. Constitutional courts in Asian cases. Cambridge: Cambridge University Press.

Hagle, Timothy M. (1993). Strategic retirements: A political model of turnover on the United

States Supreme Court. Political Behavior, 15(1), 25-48. 
Hall, Melinda Gann (2001). Voluntary retirements from state supreme courts: Assessing democratic pressures to relinquish the bench. The Journal of Politics, 63(4), 1112-1140. Hall, Melinda Gann , \& Bonneau, Chris W. (2006). Does quality matter? Challengers in state Supreme Court elections. American Journal of Political Science, 50(1).

Hansford, Thomas G. , Savchak, Elisha Carol , \& Songer, Donald R. (2010). Politics, careerism, and the voluntary departures of US district court judges. American Politics Research, 38(6), 986-1014.

Hayek, Friedrich A. (1978). The constitution of liberty. Chicago: University of Chicago Press. Hayo, Bernd , \& Voigt, Stefan (2007). Explaining de facto judicial independence. International Review of Law and Economics, 27(3), 269-290.

Helmke, Gretchen (2002). The logic of strategic defection: Court-executive relations in Argentina under dictatorship and democracy. American Political Science Review, 96(2), 291-303.

Helmke, Gretchen (2005). Courts under constraints: Judges, generals, and presidents in Argentina. New York: Cambridge University Press.

Helmke, Gretchen , \& Rosenbluth, Frances (2009). Regimes and the rule of law: Judicial independence in comparative perspective. Annual Review of Political Science, 12, 345-366. Helmke, Gretchen , \& Staton, Jeffrey K. (2011). The puzzling judicial politics in Latin America. A theory of litigation, judicial decisions, and interbranch conflict. In G. Helmke , \& J. RíosFigueroa (Eds.), Courts in Latin America. Cambridge: Cambridge University Press.

Herron, Erik S. , \& Randazzo, Kirk A. (2003). The relationship between independence and judicial review in post-communist courts. The Journal of Politics, 65(2), 422-438.

Hirschl, Ran (2004). Towards juristocracy. The origins and consequences of the New Constitutionalism. Cambridge, MA: Harvard University Press.

Holmes, Stephen (1988). Precommitment and the paradox of democracy. In J. Elster, \& R. Slagstad (Eds). Constitutionalism and democracy. Cambridge: Cambridge University Press. laryczower, Matias , Spiller, Pablo T. , \& Tommasi, Mariano (2002). Judicial independence in unstable environments, Argentina 1935-1998. American Journal of Political Science, 46(4), 699-716.

Kahn, Paul W. (1993). Independence and responsibility in the judicial role. In I. P. Stotzky (Ed.), Transition to democracy in Latin America. Boulder, CO: Westview Press.

Kerby, Matthew , \& Banfield, Andrew C. (2014). The determinants of voluntary judicial resignation in Australia, Canda and New Zealand. Commonwealth \& Comparative Politics, 52(3), 335-357.

King, Gary (1987). Appointments to the Supreme Court: Adding systematic explanation to probabilistic description. American Politics Quarterly, 15(3), 377-386.

La Porta, Rafael , López-de-Silanes, Florencio , Pop-Eleches, Cristian , \& Shleifer, Andrei (2004). Judicial checks and balances. Journal of Political Economy, 112(2), 445-469.

Landes, William M. , \& Posner, Richard A. (1975). The independent judiciary in an interestgroup perspective. Journal of Law and Economics, 18(3), 875-901.

Lara Borges, Oswald, Castagnola, Andrea , \& Pérez-Liñán, Aníbal (2012). Diseño constitucional y estabilidad judicial en América Latina, 1900-2009. Política y Gobierno, XIX(1), 3-40.

Larkins, Christopher 1996. Judicial independence and democratization: A theoretical and conceptualization analysis. American Journal of Comparative Law, 44(4), 605-626.

Madison, James , Hamilton, Alexander , \& Jay, John (1787-1788). The federalist papers (1982 ed.). New York: Bantam Classic.

Magaloni, Beatriz 2006. Voting for autocracy: Hegemonic party survival and its demise in Mexico. Cambridge: Cambridge University Press.

Massie, Tajuana, Randazzo, Kirk A. , \& Songer, Donald R. (2014). The politics of judicial retirement in Canada and the United Kingdom. Journal of Law and Courts, 2(2), 273-299. Melton, James , \& Ginsburg, Tom (2014). Does de jure judicial independence really matter? A reevaluation of explanations for judicial independence. Journal of Law and Courts, 2(2), 187-217.

Mueller, Dennis C. (1996). Constitutional democracy. New York: Oxford University Press. 
Mueller, Dennis C. (1999). Fundamental issues in constitutional reform: With special references to Latin America and the United States. Constitutional Political Economy, 10, 119-148.

Navia, Patricio , \& Ríos Figueroa, Julio (2005). The constitutional adjudication mosaic of Latin America. Comparative Political Studies, 38(2), 189-217.

Nixon, David , \& Haskin, J. David (2000). Judicial retirement strategies. The judge's role in influencing party control of the appellate courts. American Politics Quarterly, 28(4), 458-489. North, Douglass (1990). Institutions, institutional change, and economic performance. New York: Cambridge University Press.

Pérez-Liñán, Aníbal , \& Castagnola, Andrea . Forthcoming. Judicial instability and endogenous constitutional change: Lessons from Latin America. British Journal of Political Science.

Popova, Maria (2012). Politicized justices in emerging democracies. A study of courts in Russia and Ukraine. Cambridge: Cambridge University Press.

Ramseyer, Mark (1994). The puzzling (in)dependence of courts: A comparative approach. Journal of Legal Studies, 23, 721-747.

Ramseyer, J. Mark , \& Rasmusen, Eric B. (2001). Why are Japanese judges so conservative in politically charged cases? American Political Science Review, 95(2), 331-344.

Ríos-Figueroa, Julio (2006). Judicial independence: Definition, measurement, and its effects on corruption. An analysis of Latin America. Political Science, New York University, New York City.

Ríos-Figueroa, Julio (2007). Fragmentation of power and the emergence of an effective judiciary in Mexico, 1994-2002. Latin American Politics and Society, 49(1), 31-57.

Ríos-Figueroa, Julio (2011). Institutions for constitutional justice in Latin America. In G. Helmke, \& J. Ríos-Figueroa (Eds.), Courts in Latin America. Cambridge: Cambridge University Press.

Rodríguez-Raga, Juan Carlos (2011). Strategic deference in the Colombian Constitutional Court. In G. Helmke , \& J. Ríos-Figueroa (Eds.), Courts in Latin America. Cambridge: Cambridge University Press.

Schmidhauser, John R. (1962). When and why justices leave the Supreme Court. In W. Donahue, \& C. Tibbitts (Eds.), Politics of age. Ann Arbor: Division of Gerontology, University of Michigan.

Spiller, Pablo T. , \& Tommasi, Mariano (2007). The institutional foundations of public policy in Argentina. Cambridge: Cambridge University Press.

Spriggs, James F. II , \& Wahlbeck, Paul J. (1995). Calling it quits: Strategic retirement on the federal courts of appeals, 1893-1991. Political Research Quarterly, 48(3), 573-597.

Squire, Peverill (1988). Politics and personal factors in retirement from the United States Supreme Court. Political Behavior, 10(2), 180-190.

Stolzenberg, Ross M. , \& Lindgren, James (2010). Retirement and death in office of US Supreme Court justices. Demography, 47(2), 269-298.

Sunstein, Cass R. (1988). Constitutions and democracies: an epilogue. In J. Elster , \& R. Slagstad (Eds.), Constitutionalism and democracy,. Cambridge: Cambridge University Press. Sunstein, Cass R. (2001). Designing democracy. What constitutions do. New York: Oxford University Press.

Tsebelis, George (1999). Veto players and law production in parliamentary democracies: An empirical analysis. American Political Science Review, 93(3), 591-608.

Ulmer, S. S. (1982). Supreme Court appointments as a Poisson distribution. American Journal of Political Science, 26(1), 113-116.

Vile, M. J. C. (1998). Constitutionalism and the separation of power (2nd ed.). Indianapolis: Liberty Fund.

Vining, Richard L. Jr. (2009). Judicial departures and the introduction of qualified retirement, 1892-1953. Justice System Journal, 30(2), 139-157.

Vining, Richard L. Jr. , Zorn, Christopher , \& Smelcer, Susan Navarro (2006). Judicial tenure on the US Supreme Court, 1790-1868: Frustration, resignation, and expiration on the bench. Studies in American Political Development, 20(Fall), 198-210. 
VonDoepp, Peter , \& Ellett, Rachel (2011). Reworking strategic models of executive- judicial relations. Insights from new African democracies. Comparative Politics, 43(2), 147-165. Wallis, W. A. (1936). The Poisson distribution and the Supreme Court. Journal of the American Statistic Association, 31(194), 376-380.

Ward, Artemus (2003). Deciding to leave. The politics of retirement from the United States Supreme Court. New York: State University of New York.

Yoon, Albert (2003). Love's labor's lost? Judicial tenure among federal court judges:

1945-2000. California Law Review, 91, 1029-1060.

Yoon, Albert (2006). Pensions, politics, and judicial tenure: An empirical study of federal judges, 1869-2002. American Law and Economic Review, 8(1), 143-180.

Zorn, Christopher J. , \& Van Winkle, Steven R. (2000). A competing risks model of Supreme Court vacancies, 1789-1992. Political Behavior, 22(2), 145-166.

\section{The Political History of the Manipulation of the Argentinean Supreme Court}

Abiad, Pablo , \& Thieberger, Mariano (2005). Justicia Era Kirchner. Construcción de un poder a medida, Colección Urgente. Buenos Aires: Marea Editorial.

Barrancos y Vedia, Fernando N. (2000). La Corte Suprema de Justicia en la historia constitucional de Argentina. Academia Nacional de Ciencias Morales y Políticas, 201-230.

Bill Chávez, Rebecca Bill . 2007. The appointment and removal process for judges in Argentina: The role of judicial councils and impeachment juries in promoting judicial independence. Latin American Politics and Society, 49(2), 33-58.

Carrio, Alejandro (1996). La Corte Suprema y su Independencia. Buenos Aires: AbeledoPerrot.

Gatti, Daniel (2004). Kirchner, el amo del feudo. Biografía no autorizada de Néstor Kirchner. https://docs.google.com/file/d/0B_UjGlz70VGCek1UQS1SNEVqX00/edit.

Helmke, Gretchen (2005). Courts under constraints: Judges, generals, and presidents in Argentina. New York: Cambridge University Press.

Hernández, Antonio María (2001). El caso "Fayt" y sus implicancias constitucionales. Anuario iberoamericano de justicia constitucional, 453-516.

Jacquelin, Claudio A. (1998, November 29). Nueve años en la frontera. La Nación. Mainwaring, Scott , \& Pérez-Liñán, Aníbal (2013). Democracies and dictatorship in Latin America. Emergence, survival and fall. Cambridge, MA: Cambridge University Press. Molinelli, Guillermo (Ed.). (1999). La Corte Suprema de Justicia de la Nación frente a los poderes políticos, a través del control de constitucionalidad, 1983-98. Buenos Aires, Argentina: Instituto de Investigaciones "Ambrosio Gioja".

Molinelli, Guillermo , Palanza, Valeria , \& Sin, Gisela (1999). Congreso, Presidencia y Justicia en Argentina. Materiales para su estudio. Buenos Aires, Argentina: Temas.

Nino, Carlos (2005). Un pais al margen de la ley (3rd ed.). Buenos Aires: Ariel.

Oteiza, Eduardo (1994). La Corte Suprema. Entre la justicia sin política y la política sin justicia. La Plata: Librería editora Plantense S.R.L.

Oyhanarte, Julio (1972). Historia del poder Judicial. Todo es Historia, VI(61), 86-121.

Pellet Lastra, Arturo (2001). Historia Política de la Corte (1930-1990). Buenos Aires, Argentina: Ad-Hoc.

Pérez Guilhou, Dardo (1989). La Corte Suprema de Justicia y de los Gobiernos de facto (1861-1983). In D. P. Guilhou (Ed.), El Poder Judicial. Buenos Aires: Depalma.

Periodismo (2002). El juez Bossert renunció a la Corte. Era el miembro menos cuestionado. In Periodismo. Buenos Aires: www.periodismo.com/news/103528820256715.shtml.

Pierson, Paul (2004). Politics in time. History, institutions, and social analysis. Princeton and Oxford: Princeton University Press.

Poder Ciudadano (1997). Quien es quien en el Poder Judicial. Buenos Aires: Perfil. 
Poder Judicial de la Nación Argentina (2004). Estadisticas del Poder Judicial de la Nación Argentina. www.justiciaargetnina.gov.ar/estadisticas/imag_jus.htm.

Potash, Robert A. (1982a). El ejército y la política en la Argentina 1928-1945. De Yrigoyen a Perón. Buenos Aires: Editorial Sudamericana.

Potash, Robert A. (1982b). El ejército y la política en la Argentina 1945-1962. De Perón a Frondizi. Buenos Aires: Editorial Sudamericana.

Romero, Luis Alberto (2001). Breve historia contemporánea de la Argentina (2nd ed.). Buenos Aires: Fondo de Cultura Económica.

Sidicaro, Ricardo (2002). Los tres peronismos. Estado y poder económico 1946-55/ 1973-76/1989-99. Buenos Aires: Siglo veintiuno editores Argentina.

Smulovitz, Catalina (1995). Constitución y Poder Judicial en la Nueva Democracia Argentina. La Experiencia de las Instituciones. In C. Acuña (Ed.), La Nueva Matriz Política Argentina. Buenos Aires: Nueva Visión.

Smulovitz, Catalina (2005). Petitioning and creating rights. Judicialization in Argentina. In R. Sieder , A. Angell , \& L. Schjolden (Eds.), The judicialization of politics in Latin America. New York: Palgrave MacMillan.

Verbitsky, Horacio (1993). Hacer la Corte. La construcción de un poder absoluto sin justicia ni control. Buenos Aires: Edición Planeta.

Verbitsky, Horacio (2007, July 22). El Pais: Menem y Kirchner. Página 12.

Wainfeld, Mario , \& Ginzberg, Victoria (2005, June 8). Belluscio renunció a su magistratura en la Corte Suprema. Se ira el 1ero de Septiembre. Página 12.

\section{Forcing Justices off the Bench}

Abiad, Pablo , \& Thieberger, Mariano (2005). Justicia Era Kirchner. Construcción de un poder a medida, Colección Urgente. Buenos Aires: Marea Editorial.

Bill Chávez, Rebecca (2004). The rule of law in nascent democracies. Judicial politics in Argentina. Stanford, California: Stanford University Press.

Bill Chávez, Rebecca (2007). The appointment and removal process for judges in Argentina: The role of judicial councils and impeachment juries in promoting judicial independence. Latin American Politics and Society, 49(2), 33-58.

Box-Steffensmeier, Janet M. , \& Jones, Bradford S. (2004). Event history modeling. A guide for social scientists, analytical methods for social research. Cambridge: Cambridge University Press.

Carter, David B. , \& Signorino, Curtis S. (2007). Back to the future: Modeling time dependence in binary data. [cited November 2007]. Available from

www.rochester.edu/college/psc/signorino/research/CarterSignorino2007.pdf.

Cheng, Simon, \& Long, J. Scott (2007). Testing for IIA in the multinomial logit model.

Sociological Methods \& Research, 35(4), 583-600.

Hagle, Timothy M. (1993). Strategic retirements: A political model of turnover on the United States Supreme Court. Political Behavior, 15(1), 25-48.

Heckman, James J. (1981). Statistical models for discrete anel data. In C. F. Manski , \& D. McFadden (Eds.), Structural analysis of discrete data with econometric applications (pp. 114-178). Cambridge: MIT Press.

Helmke, Gretchen (2005). Courts under constraints: Judges, generals, and presidents in Argentina. New York: Cambridge University Press.

laryczower, Matias, Spiller, Pablo T. , \& Tommasi, Mariano (2002). Judicial independence in unstable environments, Argentina 1935-1998. American Journal of Political Science, 46(4), 699-716.

Kunz, Ana E. (1989). Los Magistrados de la Corte Suprema de Justicia de la Nacion (1930-1983). Cuadernos de investigaciones, 15.

Long, Scott J. (1997). Regression models for categorical and limited dependent variables (Vol. 7). Advances quantitative techniques in the social science series. Thousand Oaks, London, New Delhi: SAGE Publications. 
Pellet Lastra, Arturo (2001). Historia Política de la Corte (1930-1990). Buenos Aires, Argentina: Ad-Hoc.

Pérez-Liñán, Aníbal , \& Castagnola, Andrea (2016). Judicial instability and endogenous constitutional change: Lessons from Latin America. British Journal of Political Science, 46(2), 395-416.

Singer, Judith D. , \& Willett, John B. (2003). Applied longitudinal data analysis. Modeling change and event occurrence. Oxford: Oxford University Press.

Spriggs, James F. II , \& Wahlbeck, Paul J. (1995). Calling it quits: Strategic retirement on the Federal Courts of Appeals, 1893-1991. Political Research Quarterly, 48(3), 573-597.

Szmer, John , \& Songer, Donald R. (2005). The effects of information on the accuracy of presidential assessments of Supreme Court nominee preferences. Political Research Quarterly, 58(1), 151-160.

Tanzi, Hector Jose (2005). Historia Ideológica de la Corte Suprema de Justicia de la Nación (1930-1947). In IUSHISTORIA Revista Electronica. Buenos Aires:

www.salvador.edu.ar/juri/reih/2dadel1/I5.pdf.

Verbitsky, Horacio (1993). Hacer la Corte. La construcción de un poder absoluto sin justicia ni control. Buenos Aires: Edición Planeta.

Zorn, Christopher J. , \& Van Winkle, Steven R. (2000). A competing risks model of Supreme Court vacancies, 1789-1992. Political Behavior, 22(2), 145-166.

\section{The Persistent Manipulation of Courts}

Abiad, Pablo , \& Thieberger, Mariano (2005). Justicia Era Kirchner. Construcción De Un Poder a Medida. Colección Urgente. Buenos Aires: Marea Editorial.

Biblioteca Tribunal Superior de Justicia de Córdoba. (2007). Tribunal Superior De Justicia 1852-2007. Córdoba Ciudad Capital: Poder Judicial de la Provincia de Córdoba.

Bill Chávez, Rebecca (2004). The rule of law in nascent democracies. Judicial politics in Argentina. Stanford, California: Stanford University Press.

Box-Steffensmeier, Janet M. , \& Jones, Bradford S. (2004). Event history modeling. A guide for social scientists, Analytical Methods for Social Research. Cambridge: Cambridge University Press.

Caballero, Stella Maria (2007). Miembros Del Superior Tribunal De Justicia De Jujuy 1935-2007. San Salvador de Jujuy: Poder Judicial de la Provincia de Jujuy.

Carter, David B. , \& Signorino, Curtis S. (2007). Back to the future: Modeling time dependence in binary data. www.rochester.edu/college/psc/signorino/research/CarterSignorino2007.pdf.

Castagnola, Andrea (2010). ¿Cómo Evolucionan Nuestras Instituciones? Un Estudio Comparado De La Normativa De Las Cortes Supremas Provinciales Y Nacional Desde 1984 Hasta 2008. Buenos Aires: Asociación por los Derechos Civiles.

Castagnola, Andrea (2012). I want it all, and I want it now: The political manipulation of Argentina's provincial high courts. Journal of Politics in Latin America, 4, 39-62.

Central de Trabajadores de Neuquén. 2008. Impugnaciones de SEJUN y la CTA Neuquén. www.ctaneuquen.org.ar/spip.php?article61\&lang=es.

Centro de Estudios Sociales y Legales. (2005). Informe Anual 2005. Buenos Aires: Siglo XX Editores.

Centro de Estudios Sociales y Legales. (2007). Informe Anual 2007. Buenos Aires: Siglo XX Editores.

Córdova, Ramón Ulises (1994). Poder Judicial De La Provincia De Formosa. Formosa:

Editorial Carpe Diem.

De Luca, Miguel , Jones, Mark P. , \& Tula, Maria Ines (2002). Back rooms or ballot boxes?

Candidate nomination in Argentina. Comparative Political Studies, 35, 413-436.

Departamento Histórico-Judicial. (2006). Ministros De La Suprema Corte De Justicia 1875-2006. La Plata, Buenos Aires: Suprema Corte de Justicia de la Provincia de Buenos Aires. 
Ghiggi, Inés (2007). Superior Tribunal De Justicia De Entre Ríos. Integración 1950-1970 and 1983-2007. Paraná, Entre Ríos: Superior Tribunal de Justicia de Entre Ríos.

Instituto Nacional de Estadística y Censo de la República Argentina. (1980). Censo Nacional De Población, Hogares Y Viviendas 1980. In www.indec.gor.ar, 2001 ed. Entre Ríos .

Instituto Nacional de Estadística y Censo de la República Argentina. (1991). Censo Nacional De Población, Hogares Y Viviendas 1991. In www.indec.gor.ar, 2001 ed. Entre Ríos . Instituto Nacional de Estadística y Censo de la República Argentina. (2001a). Censo Nacional De Población, Hogares Y Viviendas 2001. In www.indec.gor.ar, 2001 ed. Insitituto Geográfico Militar (IGM).

Instituto Nacional de Estadística y Censo de la República Argentina. (2001b). Dirección de Estadísticas Sectoriales en base al Censo Nacional de Población. In www.indec.gor.ar: Dirección Nacional de Estadísticas Sociales y de Población.

Jones, Mark (2002). Explaining the high level of party discipline in the Argentine Congress. In Scott Morgenstern , \& Benito Nacif (Eds.), Legislative politics in Latin America. Cambridge: Cambridge University Press.

Lamote, Jorge (2007). Tribunal Superior De La Provincia De Santa Cruz. Santa Cruz: Tribunal Superior de Justicia de Santa Cruz.

Leiras, Marcelo , Tuñón, Guadalupe , \& Giraudy, Agustina (2015). Who wants an independent court? Political competition and Supreme Court instability in the Argentine Provinces (1984-2008). The Journal of Politcs, 77, 175-187.

Levitsky, Steven (2001a). An "organised disorganisation": Informal organisation and the persistence of local party structures in Argentine Peronism. Journal of Latin American Studies, 33, 29-65.

Levitsky, Steven (2001b). Organization and labor-based party adaptation. The transformation of Argentine Peronism in comparative perspective. World Politics, 54, 27-56.

Levitsky, Steven (2003). Transforming labor-based parties in Latin America: Argentine Peronism in comparative perspective. Cambridge: Cambridge University Press.

Mirabella de Sant, María Cristina , \& Nanni, F. Eugenio (2004). Estimación De Productos Brutos Provinciales. In Análisis Económico Regional y Nacional. San Miguel de Tucumán. Montilla Zavalía, Félix Alberto (2007). Historia Del Poder Judicial De Tucumán (1950-2005). San Miguel de Tucumán: Edición oficial Poder Judicial de Tucumán.

Nixon, David , \& Haskin, J. David (2000). Judicial retirement strategies. The judge's role in influencing party control of the appellate courts. American Politics Quarterly, 28, 458-489.

Pelaez, Laura Mariel (2007). Conformación Del Tribunal Superior De Justicia De Poder Judicial de la Provincia de La Pampa (2009). Magistrados Y Funcionarios Desde 1954. www.juslapampa.gov.ar?formularios/historia/magistrados.php.

Poder Judicial de la Provincia de Mendoza. (2009). Suprema Corte De Justicia De La Provincia De Mendoza. ed. Departamento de Ceremonial y Protocolo. Mendoza. Poder Judicial de la Provincia de Río Negro. (2009). Superior Tribunal De Justicia. Composición 1959-2007. ed. centro de Documentación Jurídica. Viedma, Río Negro. Poder Judicial de la Provincia del Chaco. (2009). Integración Del Superior Tribunal De Justicia De La Provincia Del Chaco Desde 1953. ed. Poder Judicial. Resistencia, Chaco. Poder Judicial de la Provincia del Chubut. Nuestra Historia. (2007). www.juschubut.gov.ar/06_historia/galeria.htm.

Ramonet, Gabriel (2007). Justicia Adicta: Breve Historia Del Poder Judicial De Tierra Del Fuego (1994-2007). Ushuaia, Tierra del Fuego: Editorial Utopias.

Squire, Peverill (1988). Politics and personal factors in retirement from the United States Supreme Court. Political Behavior, 10, 180-190.

Wickström, Lloyd Jorge (2008). El Renovado Imperio De La Corrupción. Paraná: Entre Ríos. Zorn, Christopher J. , \& Van Winkle Steven R. (2000). A competing risks model of Supreme Court vacancies, 1789-1992. Political Behavior, 22, 145-166. 


\section{The Institutional Determinants of Judicial Turnover at the Subnational Level}

Bielsa, Rafael , \& Graña, Eduardo (1999). Manual De La Justicia Nacional. Buenos Aires: Ciudad Argentina.

Bill Chavez, Rebecca (2003). The construction of the rule of law in Argentina: A tale of two provinces. Comparative Politics, 35, 417-437.

Bill Chávez, Rebecca (2004). The rule of law in nascent democracies. Judicial politics in Argentina. Stanford, California: Stanford University Press.

Camps, Carlos E. (2000). El Jurado De Enjuiciamiento De Magistrados De La Nación Y Los Primeros Hitos De Su Jurisprudencia. Lexis No. 0003/007936.

Castagnola, Andrea (2010). ¿Cómo Evolucionan Nuestras Instituciones? Un Estudio Comparado De La Normativa De Las Cortes Supremas Provinciales Y Nacional Desde 1984 Hasta 2008. Buenos Aires: Asociación por los Derechos Civiles.

Centro de Estudios Nelson Mandela. (2008, October 2). Documento Crítico Del Centro Mandela Sobre El Consejo De La Magistratura. Diario Norte.

DeMaris, Alfred (2004). Regression with social data: Modeling continuous and limited response variables, Wiley Series in Probability and Statistics. New Jersey: Wiley.

Gargarella, Roberto (1997). Lala Dificultad De Defender El Control Judicial De Las Leyes. Isonomía, 6.

laryczower, Matias, Spiller, Pablo T. , \& Tommasi, Mariano (2002). Judicial independence in unstable environments, Argentina 1935-1998. American Journal of Political Science, 46, 699-716.

Kennedy, Peter (2003). A guide to econometrics (5th ed.). Cambridge, MA: MIT Press. King, Gary (1998). Unifying political methodology: The likelihood theory of statistical inference, techniques in political analysis. Ann Arbor: University of Michigan Press.

Leiras, Marcelo , Tuñón, Guadalupe , \& Giraudy, Agustina (2015). Who wants an independent court? Political competition and Supreme Court instability in the Argentine provinces (1984-2008). The Journal of Politics, 77, 175-187.

Long, Scott J. (1997). Regression models for categorical and limited dependent variables. Vol. 7, Advances Quantitative Techniques in the Social Science Series. Thousand Oaks, London, New Delhi: SAGE Publications.

Long, Scott , \& Freese, Jeremy (2006). Regression models for categorical dependent variables using Stata (2nd ed.) College Station, Texas: STATA Press.

Madison, James , Hamilton, Alexander , \& Jay, John (1787-1788). The federalist papers (1982 ed.). New York: Bantam Classic.

Pérez-Liñán, Aníbal , \& Castagnola, Andrea (2016). Judicial instability and endogenous constitutional change: Lessons from Latin America. British Journal of Political Science, 46, 395-416.

Ríos-Figueroa, Julio (2006). Judicial independence: Definition, measurement, and its effects on corruption. An analysis of Latin America. New York University.

Sabsay, Daniel Alberto (2004). El Juicio Político a La Corte Suprema En La República Argentina. Anuario Iberoamericano de Justicia Constitucional, 8.

\section{Conclusion}

Albuja Martínez, Marco (2008). Reorganizaciones de la Corte Suprema de Justicia. Quito, Ecuador: Lexis-Nexis Ecuador.

Ávila, Luis F. (2004). Efectos de la Declaratoria de Inconstitucionalidad en el Ecuador. Quito, Ecuador: Corporación de Estudios y Publicaciones.

Baum, Lawrence (1998). The Supreme Court (6th ed.). Washington, DC: CQ Press.

Bill Chávez, Rebecca (2004). The rule of law in nascent democracies. Judicial politics in Argentina. Stanford, California: Stanford University Press. 
Grijalva, Agustín (2010). Courts and political parties: The politics of constitutional review in Ecuador. Political Science, University of Pittsburgh, Pittsburgh.

Helmke, Gretchen (2002). The logic of strategic defection: Court-executive relations in Argentina under dictatorship and democracy. American Political Science Review, 96(2), 291-303.

Helmke, Gretchen (2005). Courts under constraints: Judges, generals, and presidents in Argentina. New York: Cambridge University Press.

laryczower, Matias, Spiller, Pablo T. , \& Tommasi, Mariano (2002). Judicial independence in unstable environments, Argentina 1935-1998. American Journal of Political Science, 46(4), 699-716.

Mejía Acosta, Andrés (2006). Crafting legislative ghost coalitions in Ecuador. Informal institutions and economic reform in an unlikely case. In G. Helmke , \& S. Levitsky (Eds.), Informal institutions \& democracy. Lessons from Latin America (pp. 69-84). Baltimore, Maryland: The Johns Hopkins University Press.

Ordóñez Espinosa, Hugo (2000). Sobre la Evolución de la Dogmática Constitucional en el Ecuador. Quito, Ecuador: Corporación de Estudios y Publicaciones.

Pérez Liñán, Aníbal , \& Castagnola, Andrea (2009). Presidential control of high courts in Latin America: A long term view (1904-2006). Journal of Politics in Latin America, 2, 87-114.

Pompe, Sebastiaan (2005). The Indonesian Supreme Court. A study of institutional collapse. Cornell Southeast Asia Program Publication. Ithaca, NY: Cornell University.

Scribner, Druscilla (2004). Limiting presidential power: Supreme Court-executive relations in Argentina and Chile. Political Science, University of California, San Diego, California.

Segal, Jeffrey A. , \& Spaeth, Harold J. (2002). The Supreme Court and the attitudinal model revisted. Cambridge: Cambridge University Press.

Shugart, Matthew S. (1995). The electoral cycle and institutional sources of divided presidential goverment. American Political Science Review, 89(2), 327-343.

Shugart, Matthew S. , \& Carey, John M. (1992). Presidents and assemblies: Constitutional design and electoral dynamics. Cambridge, UK; New York: Cambridge University Press.

Stokes, Susan C. (2001). Economic reform and public opinion in Fujimori's Peru. In S. C. Stokes (Ed.), Public support for market reforms in new democracies. Cambridge, UK; New York: Cambridge University Press.

Trochev, Alexei (2008). Judging Russia. Constitutional court in Russian politics 1990-2006. Cambridge, UK: Cambridge University Press. 